\title{
Seasonal changes in testicular size and serum LH, prolactin and testosterone concentrations in male polar bears (Ursus maritimus)
}

\author{
L. A. Howell-Skalla ${ }^{*}$, M. R. L. Cattet ${ }^{2}$, M. A. Ramsay ${ }^{3+}$ \\ and J. M. Bahr ${ }^{*}$ \\ ${ }^{1}$ Department of Animal Sciences, University of Illinois, Urbana, IL 61801, USA; \\ ${ }^{2}$ Department of Veterinary Pathology, Western College of Veterinary Medicine, \\ University of Saskatchewan, Saskatoon, SK S7N 5B4, Canada; and ${ }^{3}$ Department of Biology, \\ University of Saskatchewan, Saskatoon, SK S7N 5E2, Canada
}

Little is known about the reproductive endocrinology of the male polar bear, Ursus maritimus, except that serum testosterone concentrations are high in April and May during the mating season and are low from August to November during the non-mating season. The objective of this study was to describe the relationship between seasonal changes in testicular size and serum concentrations of testosterone, $\mathrm{LH}$ and prolactin. Blood samples and testicular measurements were obtained from freeranging male polar bears in Canada in April $(n=5)$ and May $(n=15)$ near Resolute Bay, Northwest Territories and near Churchill, Manitoba in July $(n=15)$ and October $(n=22)$. Testis size was greater in May $\left(39.4 \pm 3.5 \mathrm{~cm}^{2}\right)$ than in October $\left(27.3 \pm 2.0 \mathrm{~cm}^{2}\right) \quad(P=0.002)$. Serum testosterone concentrations were approximately threefold higher in April $\left(5.8 \pm 0.8 \mathrm{ng} \mathrm{ml}^{-1}\right)$ than in May $\left(1.7 \pm 0.5 \mathrm{ng} \mathrm{ml}^{-1}\right)$, July $\left(0.6 \pm 0.2 \mathrm{ng} \mathrm{ml}^{-1}\right)$ and October $\left(1.1 \pm 0.2 \mathrm{ng} \mathrm{ml}^{-1}\right)$. Similarly, serum LH concentrations were high in April $\left(0.14 \pm 0.04 \mathrm{ng} \mathrm{ml}^{-1}\right)$ and low in May $\left(0.09 \pm 0.01 \mathrm{ng} \mathrm{ml}^{-1}\right)$, July $\left(0.10 \pm 0.02 \mathrm{ng} \mathrm{ml}^{-1}\right)$ and October $\left(0.08 \pm 0.00 \mathrm{ng} \mathrm{ml}^{-1}\right)$. Serum prolactin concentrations were high in April $\left(1.9 \pm 0.3 \mathrm{ng} \mathrm{ml}^{-1}\right)$, highest in May $\left(2.5 \pm 0.2 \mathrm{ng} \mathrm{ml}^{-1}\right)$, lower in July $\left(1.3 \pm 0.1 \mathrm{ng} \mathrm{ml}^{-1}\right)$ and lowest in October $\left(0.8 \pm 0.07 \mathrm{ng} \mathrm{ml}^{-1}\right)$. The present study demonstrates a positive relationship between testicular size and serum concentrations of $\mathrm{LH}$, prolactin and testosterone in the male polar bear and confirms the previously reported seasonal changes in serum testosterone concentrations. Data from the present study provide important baseline and comparative endocrine information that can be used to aid captive breeding programmes in zoos and to further ecological-behavioural studies of polar bears.

\section{Introduction}

The polar bear (Ursus maritimus) is one of eight species of bear alive today. Polar bears live in coastal habitats of the circumpolar Arctic, including Canada, USA, Norway, Greenland and Russia. The polar bear was once considered to be a threatened species; however, the current world population is believed to be stable and estimated to be between 22000 and 27000 bears (Derocher et al., 1998). Although much is known about the ecology of polar bears, there is little information regarding their reproductive biology. As in other species of temperate region bears (black, Ursus americanus; brown, Ursus arctos), polar bears mate during periods of increasing daylength in the spring, but implantation of the blastocyst is delayed until autumn, when pregnant females enter their dens (Wimsatt, 1963; Lønø, 1970, 1972; Mead, 1989). In support of these

*Correspondence address: Department of Animal Sciences, University of Illinois, 1207 W. Gregory Dr, Urbana, IL 61801, USA ${ }^{\dagger}$ Deceased

Email: j-bahr@uiuc.edu findings, studies have shown increased serum progesterone concentrations in female polar bears near the time of implantation (Ramsay and Stirling, 1988; Derocher et al., 1992).

Little is known about the reproductive biology of male polar bears. Males reach sexual maturity at approximately 6 years of age but do not begin mating until 8-10 years of age (Stirling, 1988). Palmer et al. (1988) reported that the profile of serum testosterone concentrations in male polar bears is similar temporally to that of male black bears. Serum testosterone concentrations were low in autumn (August-November) during the non-breeding season and then increased markedly in spring (April-May) during the breeding season. Although not determined in this study, Palmer et al. (1988) assumed that the seasonal changes in serum testosterone concentrations were correlated with changes in testis size, as observed in the black bear (McMillen et al., 1976). Other parameters of reproductive endocrinology, such as seasonal changes in serum concentrations of $\mathrm{LH}$ and prolactin have not been examined in male polar bears.

The purpose of the present study was to expand the current knowledge of reproductive endocrinology of male 
polar bears. The objectives of the study were (i) to determine whether there was an association between testicular size and serum testosterone concentrations and (ii) to determine whether serum concentrations of $\mathrm{LH}$ and prolactin change seasonally.

\section{Materials and Methods}

\section{General}

Fifty-seven free-ranging, adult male polar bears were captured between May 1995 and November 1996. All bears were located from a helicopter and then anaesthetized with Telazol ${ }^{\circledR}$ (Fort Dodge Laboratories Inc., Fort Dodge, IA) using remote injection equipment (Stirling et al., 1989). Twenty male bears were captured during the breeding season (April, $n=5$; May, $n=15$ ) on sea ice in the Canadian central Arctic, near Resolute Bay, Northwest Territories. Thirty-seven bears were captured during the non-breeding season (July, $n=15$; October-November, $n=22$ ) on land near Churchill, Manitoba. Straight-line body length was measured to the nearest $\mathrm{cm}$ between the distal tips of the rostrum and tail with the bear positioned in sternal recumbency and its head and vertebral column aligned linearly. The age of the bears was determined by extracting a vestigial premolar tooth and then sectioning the tooth and counting the cementum annuli (Calvert and Ramsay, 1998). Testicular dimensions were determined with calipers and recorded as the length from the cranial to the caudal pole, and the width at the greatest sagittal circumference. The dimensions for each bear were recorded as the mean values of both testes. Blood samples were collected via an i.v. catheter that was aseptically secured in the jugular vein of anesthetized bears and $20 \mathrm{ml}$ of blood was removed via an infusion cap. Blood collection was performed within $25 \mathrm{~min}$ of the initial disturbance of the bears. Blood samples were rapidly cooled and then centrifuged at $2134 \mathrm{~g}$ for 10 min to collect serum. The frozen serum was subsequently shipped on dry ice to the University of Illinois at UrbanaChampaign and stored at $-20^{\circ} \mathrm{C}$ until analysed by radioimmunoassay.

\section{Radioimmunoassays}

The heterologous radioimmunoassay used to determine LH concentrations in bear serum was established previously and validated in our laboratory by parallelism and recovery of unlabelled LH (Horan et al., 1993). A monoclonal antibovine LH antibody (lot no. 2, 518B 7 ), which detects LH from many different mammalian species (Matteri et al., 1987) was provided by J. Roser at the University of California-Davis. Purified bovine LH (USDA-bLH-B-6) was provided by J. Proudman (USDA Animal Hormone Program). Intra- and interassay coefficients of variation were $3.9(n=6)$ and $6.3 \%(n=7)$, respectively. Sensitivity of the assay was $80 \mathrm{pg}$. Bear serum prolactin concentrations were determined by a heterologous radioimmunoassy established previously and validated in our laboratory (Tsubota et al., 1995). Purified pig prolactin (USDA-pPRL-B-1) used for iodination and standards and primary antiserum (goat antipig prolactin) were provided by D. J. Bolt (USDA Animal Hormone Program). Intra- and interassay coefficients of variation were $7.1(n=6)$ and $9.2 \%(n=7)$, respectively. Sensitivity of the assay was $30 \mathrm{pg}$. Serum testosterone concentrations were determined in double extracted bear serum with a radioimmunoassay previously validated in our laboratory by column chromatography, parallelism and recovery of unlabelled ligand (Palmer et al., 1988). The crossreactivity of the antiserum was reported by Bahr et al. (1983). Sensitivity of the testosterone assay is $8 \mathrm{pg}$. Recovery of labelled testosterone (1000 c.p.m.) added to serum before extraction was $>70 \%$. Intra- and interassay coefficients of variation were $3.5(n=4)$ and $10.2 \%(n=16)$, respectively. Hormone concentrations were determined using the RIAEIA Parallelism Program with Hot Recovery written by M-C. J. Wu (Taiwan Livestock Research Institute, Hsinhua).

\section{Statistical analysis}

Mean testicular size and hormone concentrations were compared by season using a one-way ANOVA with PROC GLM (SAS, 1985). Means were log transformed before statistical analysis to reduce the heterogeneity of variance. When a significant difference was found, multiple comparisons of means were made using the least significant differences test. Two values for testosterone concentrations in April and one value for testosterone concentrations in May were removed from the final analysis of data because these values were more than two standard deviations different from the means. Data are presented as means \pm SEM. Differences were considered significant at $P<0.05$.

\section{Results}

Male polar bears become adults at 5 years of age. The polar bears sampled ranged in age from 5 to 20 years. Body length did not differ with season, location of sampling or age. Body length ranged from 196 to $247 \mathrm{~cm}$. Testicular size changed seasonally (Fig. 1); testicular size was greater in May $\left(39.4 \pm 3.5 \mathrm{~cm}^{2}\right)$ than in October $\left(27.3 \pm 2.0 \mathrm{~cm}^{2}\right)$ $(P=0.002)$. Serum testosterone concentrations (Fig. 2) were approximately three-fold higher in April (5.8 $\left.\pm 0.8 \mathrm{ng} \mathrm{ml}^{-1}\right)$ than in May $\left(1.7 \pm 0.5 \mathrm{ng} \mathrm{ml}^{-1}\right)$, July $\left(0.6 \pm 0.2 \mathrm{ng} \mathrm{ml}^{-1}\right)$ and October $\left(1.1 \pm 0.2 \mathrm{ng} \mathrm{ml}^{-1}\right)(P<0.05)$. Serum testosterone concentrations were lowest in July with similar concentrations in May and October. Serum LH concentrations (Fig. 3) were highest in April $\left(0.14 \pm 0.04 \mathrm{ng} \mathrm{ml}^{-1}\right)$ during the breeding season and low in May $\left(0.09 \pm 0.01 \mathrm{ng} \mathrm{ml}^{-1}\right)$, July $\left(0.10 \pm 0.02 \mathrm{ng} \mathrm{m}^{-1}\right)$ and October $\left(0.08 \pm 0.0 \mathrm{ng} \mathrm{ml}^{-1}\right)$. Serum prolactin concentrations (Fig. 4) were high in April $\left(1.9 \pm 0.3 \mathrm{ng} \mathrm{ml}^{-1}\right)$, highest in May $\left(2.5 \pm 0.2 \mathrm{ng} \mathrm{ml}^{-1}\right)$, lower in July $\left(1.3 \pm 0.1 \mathrm{ng} \mathrm{ml}^{-1}\right)$ and lowest in October $\left(0.8 \pm 0.07 \mathrm{ng} \mathrm{ml}^{-1}\right)$. 


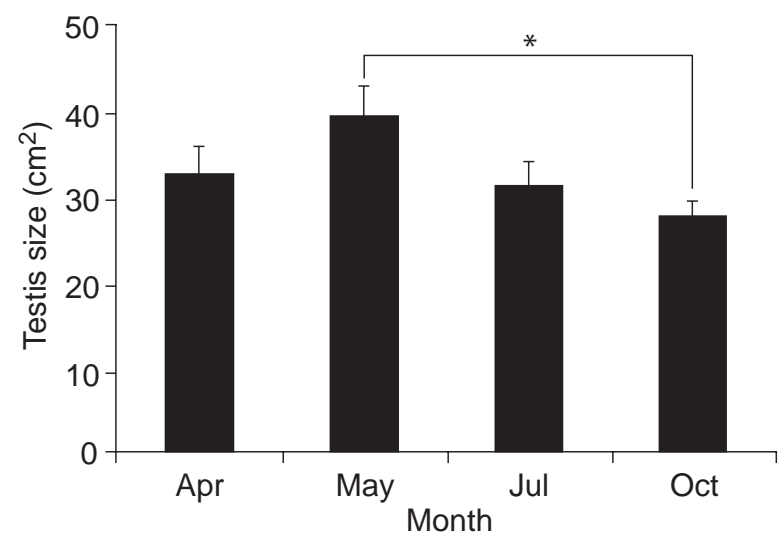

Fig. 1. Seasonal changes in testicular size in male polar bears (Ursus maritimus). Testicular dimensions (length and width) were determined for the right and left testes and the average measurement was taken. Bars represent testis size in $\mathrm{cm}^{2}$ (length $\times$ width) $($ mean \pm SEM). $* P=0.002$.

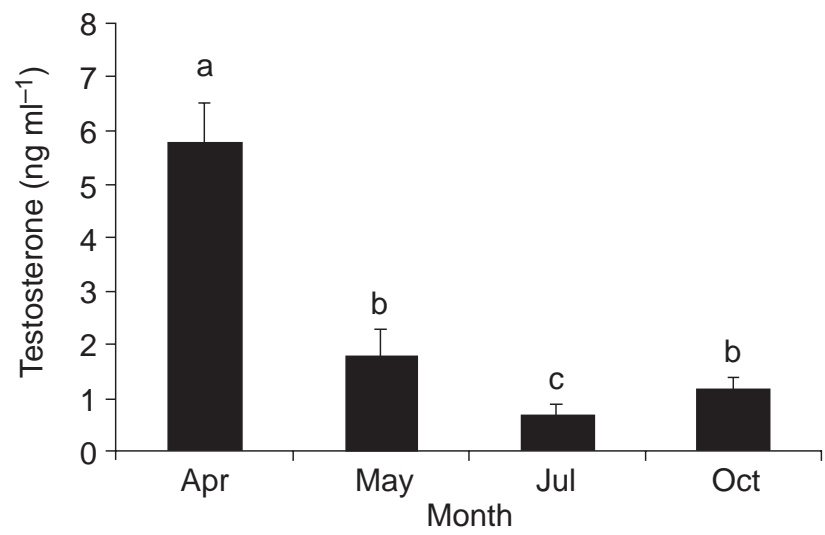

Fig. 2. Seasonal changes in serum testosterone concentrations in male polar bears (Ursus maritimus). Each bar represents serum testosterone concentrations in $\mathrm{ng} \mathrm{ml}^{-1}$ (mean \pm SEM). ${ }^{\text {abc Different }}$ letters indicate significant differences among months $(P<0.05)$.

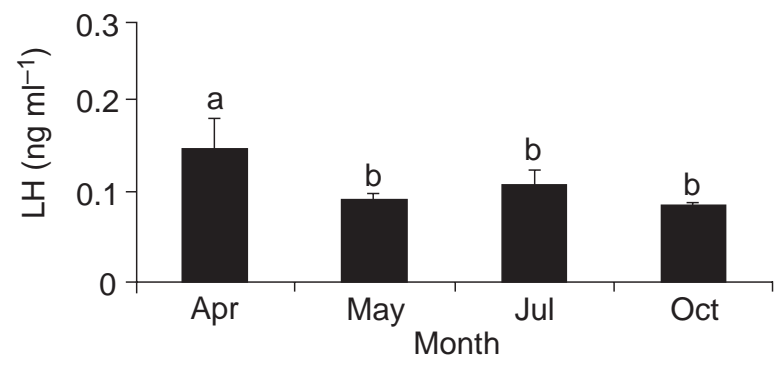

Fig. 3. Seasonal changes in serum LH concentrations in male polar bears (Ursus maritimus). Each bar represents serum LH concentrations in $\mathrm{ng} \mathrm{ml}^{-1}$ (mean $\pm \mathrm{SEM}$ ). ${ }^{\mathrm{ab}}$ Different letters indicate differences among months.

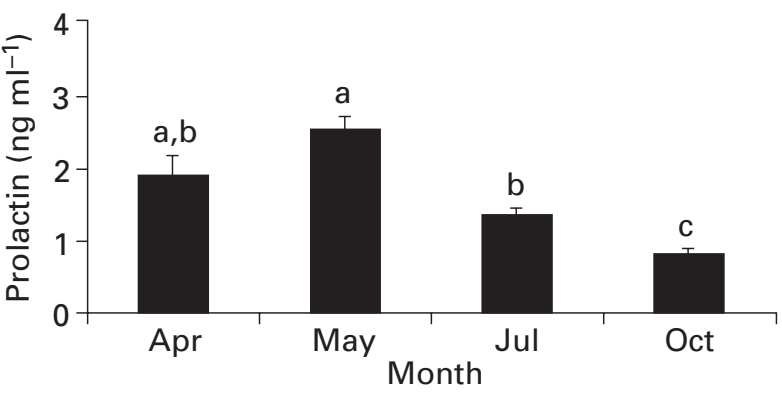

Fig. 4. Seasonal changes in serum prolactin concentrations in male polar bears (Ursus maritimus). Each bar represents serum prolactin concentrations in $\mathrm{ng} \mathrm{ml}^{-1}$ (mean $\pm \mathrm{SEM}$ ). abcDifferent letters indicate significant differences among months $(P<0.05)$.

\section{Discussion}

The present report is the first to describe the relationship between serum testosterone, $\mathrm{LH}$ and prolactin concentrations and testicular size in male polar bears. The present study determined that (i) testis size was greater in April and May during the breeding season than in July or October during the non-breeding season; (ii) serum testosterone concentrations were highest in April, decreased in May and were very low in July and October; (iii) serum $\mathrm{LH}$ concentrations were highest in April, coincident with peak serum testosterone concentrations; and (iv) serum prolactin concentrations were higher in April and May coincident with increasing daylength and lower in July and October coincident with decreasing daylength. These findings contribute significantly to the understanding of the reproductive endocrinology of male polar bears.

This is the first report of seasonal changes in testis size in polar bears. In the black bear, testicular regression occurs from July to December, whereas testicular recrudescence occurs from mid-January to May (Erickson and Nellor, 1964; McMillen et al., 1976; Horan et al., 1993; Tsubota et al., 1997). The seasonal pattern in testicular size in the polar bear was similar to that of the black bear; however, the overall change in size was smaller. In October, the regressed testis of the polar bear was $69 \%$ of the seasonal maximum measured in May in contrast to the black bear in which the regressed testis in January was $45 \%$ of the seasonal maximum measured in May (Howell-Skalla et al., 2000). Typically, the most marked examples of testicular regression occur in species with the shortest breeding season (Lincoln, 1989). Therefore, a greater difference in testis size was expected on the basis of the short mating season of the polar bear.

In general, testicular size was positively correlated with serum testosterone concentrations both of which were higher during the mating season in April and May than during the period of reproductive inactivity in July and October. This profile in serum testosterone concentrations is similar to that observed by Palmer et al. (1988); however, 
a much greater difference was observed in the present study between serum testosterone concentrations collected in April and May. This difference could be attributed to the small sample size used in April. Palmer et al. (1988) sampled 43 bears in April and 20 in May, whereas in the present study, only five bears were sampled in April and 15 bears in May. The sample size used in April was reduced to $n=3$ and to $n=14$ in May because of extremely high values $\left(18,32\right.$ and $\left.40 \mathrm{ng} \mathrm{ml}^{-1}\right)$ that were considered statistical outliers. However, it should be noted that Palmer et al. (1988) demonstrated a linear relationship between age and serum testosterone concentrations in male polar bears during the breeding season. Indeed, the values excluded from analysis in the present study were from older bears (11-21 years of age) and these values did fall within the range observed in older bears by Palmer et al. (1988).

High serum testosterone concentrations in April are coincident with the peak of the mating season, which extends from late March to May in polar bears (Lønø, 1970). High testosterone concentrations are likely to be critical for the reproductive success of a male polar bear. Polar bears do not maintain stable territories because of the unpredictability of the sea ice and consequently of the location of their main food source, the ringed seal (Stirling and McEwan, 1975; Smith and Stirling, 1978; Smith, 1980; Nemoto and Harrison, 1981; Ramsay and Stirling, 1986). The distribution of female polar bears is unpredictable and results in intense competition among males for mates. Female polar bears remain with their cubs for 2 to 3 years and, therefore, are available for breeding only every 3 years. This situation creates a skewed sex ratio of at least two to three males available for every female and greatly intensifies the competition among males (Ramsay and Stirling, 1986). Breeding opportunities are determined by intrasexual fighting and dominance displays and as a result, male polar bears are extremely aggressive during the mating season (Ramsay and Stirling, 1986). Testosterone is known to facilitate aggressive behaviour (Lincoln, 1971; Lincoln and Davidson, 1977; Lincoln, 1989) and is linked directly to increased male-male interactions during the breeding season.

The rapid decrease in serum testosterone concentrations in May appears to be associated with the end of the breeding season and may bring an end to social aggression among males. This idea is supported by Bartsh et al. (1992) who reported that in Antarctic Weddel seals, serum testosterone concentrations decreased suddenly either after males were rebuffed from attaining a breeding territory or if they were forced into submission. In addition, peak serum testosterone concentration in male Weddel seals was attained 2 weeks before the actual mating period and then decreased steadily throughout the remainder of the breeding season. More frequent blood sampling correlated with behavioural observations are needed to determine the exact relationship between serum testosterone concentrations and breeding behaviour in male polar bears.

Serum LH concentrations were increased in April, coincident with peak serum testosterone concentrations. This finding supports a study by Horan et al. (1993) in which testosterone production in the black bear was demonstrated to be closely associated with $\mathrm{LH}$ release from the pituitary gland in response to $\mathrm{GnRH}$. Seasonal differences in basal serum LH concentrations in black bears have not been detected (Horan et al., 1993; Howell-Skalla et al., 2000); however, average serum testosterone concentrations in black bears were much lower than in sampled polar bears.

Finally, the present study is the first report of seasonal changes in serum prolactin concentrations in polar bears. Circulating prolactin concentrations in male polar bears increased with increasing daylength (April to May) and decreased with decreasing daylength (July and November) as has been described in all other seasonal breeders (Curlewis, 1992). In black bears, serum prolactin concentrations are lowest during the short days of autumn and winter and then increase steadily during the spring (Tsubota et al., 1995). Changes in prolactin secretion appear to play a role in seasonal testicular function although the exact role of prolactin varies with species (Bartke et al., 1975; Bex et al., 1978; Curlewis, 1992). Howell-Skalla et al. (2000) demonstrated that, in black bears, preventing the spring increase in serum prolactin concentrations with a longacting form of bromocriptine resulted in lower serum testosterone concentrations and prevented both an upregulation of testicular $\mathrm{LH}$ receptors and maximal testicular growth.

The hormone data in the present study were taken from free-ranging anaesthetized polar bears. However, the validity of the values due to the effects of the anaesthetic is of concern. Telazol has been used in many studies on bears as the anaesthetic of choice. In another study, Horan et al. (1993) collected repeated blood samples for LH and testosterone measurements over $3 \mathrm{~h}$. During the first hour of sampling, before an injection of $\mathrm{GnRH}$ to determine pituitary gland responsiveness, serum concentrations of $\mathrm{LH}$ were very constant and injection with $\mathrm{GnRH}$ produced a robust increase in $\mathrm{LH}$ and testosterone depending on the season. Furthermore, in this study, the uniform treatment of all bears with Telazol and consistent capture and handling procedures, makes any effects of capture and handling a fairly constant factor which should not confound the analysis of the effects of other variables.

In summary, the present study reports seasonal changes in testicular endocrine function in the male polar bear. These findings contribute significantly to the field of bear reproduction because so little is currently known. Baseline endocrine information in male polar bears can be applied to captive breeding programmes in zoos and to ongoing behavioural ecology studies in the field.

The authors thank K. Burke, Jr., M. Dyck, A. Hann, S. Miller and S. Polischuk for assisting in collecting field data. Research was funded in part by operating grants from the US National Science Foundation and the National Science and Engineering Research Council of Canada. 


\section{References}

Bahr JM, Wang S-C, Huang M and Calvo F (1983) Steroid concentrations in isolated theca and granulosa layers of preovulatory follicles during the ovulatory cycle of the domestic hen Biology of Reproduction 29 326-334

Bartke A, Croft B and Dalterio S (1975) Prolactin restores plasma testosterone levels and stimulates testicular growth in hamsters exposed to short daylength Endocrinology 97 1601-1604

Bartsh S, Johnston S and Siniff D (1992) Territorial behavior and breeding frequency of male Weddel seals (Leptonychotes weddelli) in relation to age, size, and concentrations of serum testosterone and cortisol Canadian Journal of Zoology 70 680-692

Bex F, Bartke A, Goldman B and Dalterio S (1978) Prolactin, growth hormone and luteinizing hormone receptors and seasonal changes in testicular activity in the golden hamster Endocrinology 103 2069-2080

Calvert W and Ramsay MA (1998) Evaluation of age determination of polar bears by counts of cementum growth layer groups Ursus 10 449-453

Curlewis J (1992) Seasonal prolactin secretion and its role in seasonal reproduction: a review Reproduction, Fertility and Development 4 1-23

Derocher A, Stirling I and Andriashek D (1992) Pregnancy rates and serum progesterone levels of polar bears in western Hudson Bay Canadian Journal of Zoology 70 561-566

Derocher A, Garner G, Lunn N and Wiig Ø (1998) Polar Bears: Proceedings of the Twelfth Working Meeting of the IUCN/SSC Polar Bear Specialist Group. Oslo, Norway. Occasional Paper of the IUCN Species Survival Commission. No. 19 pp 159

Erickson AW and Nellor JE (1964) Breeding biology of the black bear. In The Black Bear in Michigan pp 5-45 Eds AW Erickson, J Nellor and GA Petrides. Michigan State University Agriculture Experimental Station Research Bulletin 4, East Lansing

Horan K, Nelson R, Palmer S and Bahr JM (1993) Seasonal response of the pituitary and testes to gonadotropin-releasing hormone in the black bear (Ursus americanus) Comparative Biochemistry and Physiology 106A 175-182

Howell-Skalla LA, Bunick D, Nelson RA and Bahr JM (2000) Testicular recrudescence in the male black bear (Ursus americanus): changes in testicular luteinizing hormone-, follicle-stimulating- and prolactinreceptor ribonucleic acid abundance and dependency on prolactin Biology of Reproduction 63 440-447

Lincoln G (1971) Puberty in a seasonally breeding male, the red deer stag (Cervus elephus L.) Journal of Reproduction and Fertility 25 41-54

Lincoln G (1989) Seasonal aspects of testicular function. In The Testis pp 329-385 Ed. D de Krestser. Raven Press, New York

Lincoln G and Davidson W (1977) The relationship between sexual and aggressive behavior, and pituitary and testicular activity during the seasonal sexual cycle of rams, and the influence of photoperiod Journal of Reproduction and Fertility 49 267-276

Lønø O (1970) The polar bear (Ursus maritimus) in the Svalbard area Nor Polarinst Skr 149 1-117

Lønø O (1972) Polar bear fetuses found in Svalbard Nor Polarinst Arbok 149 294-298
McMillen J, Seal U, Rogers L and Erickson A (1976) Annual testosterone rhythm in the black bear (Ursus americanus) Biology of Reproduction 15 163-167

Matteri R, Roser J, Baldwin D, Lipovetsky V and Papkoff H (1987) Characterization of a monoclonal antibody which detects luteinizing hormone from diverse mammalian species Domestic Animal Endocrinology 4 157-165

Mead R (1989) The physiology and evolution of delayed implantation in carnivores. In Carnivore Behavior, Ecology and Evolution pp 437-464 Ed. J Gittleman. Cornell University Press, Ithaca

Nemoto T and Harrison G (1981) High latitude ecosystems. In Analysis of Marine Ecosystems pp 95-126 Ed. A Longhurst. Academic Press, London

Palmer S, Nelson R, Ramsay M, Stirling I and Bahr J M (1988) Annual changes in serum sex steroids in male and female black (Ursus americanus) and polar (Ursus maritimus) bears Biology of Reproduction 38 1044-1050

Ramsay M and Stirling I (1986) On the mating system of polar bears Canadian Journal of Zoology 64 2142-2151

Ramsay M and Stirling I (1988) Reproductive biology and ecology of female polar bears (Ursus maritimus) Journal of Zoology London 214 601-634

SAS (1985) SAS User's Guide: Statistics. SAS Institute Inc, Cary, NC

Smith T (1980) Polar bear predation of ringed and bearded seals in the landfast sea ice habitat Canadian Journal of Zoology 58 2201-2209

Smith T and Stirling I (1978) Variation in the density of ringed seal (Phoco hispida) birth lairs in the Amundsen Gulf, Northwest Territories Canadian Journal of Zoology 56 1066-1071

Stirling I (1988) Polar Bears, University of Michigan Press, Ann Arbor

Stirling I and McEwan E (1975) The caloric value of whole ringed seals (Phoca hispida) in relation to polar bear (Ursus maritimus) ecology and hunting behavior Canadian Journal of Zoology 53 1021-1027

Stirling I, Spencer C and Andriashek D (1989) Immobilization of polar bears (Ursus maritimus) with Telazol in the Canadian arctic Journal of Wildlife Diseases 25 159-168

Tsubota T, Nelson R, Thulin J, Howell L and Bahr J M (1995) Annual changes in serum concentrations of prolactin in captive male black bears (Ursus americanus) Journal of Reproduction and Fertility 104 187-191

Tsubota T, Howell-Skalla L, Nitta H, Osawa Y, Mason J, Meiers P, Nelson R and Bahr JM (1997) Seasonal changes in spermatogenesis and testicular steroidogenesis in the male black bear (Ursus americanus) Journal of Reproduction and Fertility 109 21-27

Wimsatt W (1963) Delayed implantation in the Ursidae, with particular reference to the black bear (Ursus americanus) In Delayed Implantation pp 49-76 Ed. AC Enders. University of Chicago Press, Chicago

Received 14 August 2001.

First decision 19 October 2001.

Revised manuscript received 11 January 2002.

Accepted 11 January 2002. 